\title{
The Effect of Role Conflict and Emotional Fatigue on Organizational Commitment through Job Satisfaction (Study on Madrasah Aliyah Teachers in Mataram)
}

\author{
Mulyani Nouriska \\ Faculty of Economics and Business \\ Mataram University \\ Mataram, Indonesia \\ mnouriska19@gmail.com
}

\author{
Akhmad Saufi \\ Faculty of Economics and Business \\ Mataram University \\ Mataram, Indonesia \\ Akh.saufi72@gmail.com
}

\author{
Surati \\ Faculty of Economics and Business \\ Mataram University \\ Mataram, Indonesia \\ surati@gmail.com
}

DOI: $10.31364 / \mathrm{SCIRJ} / \mathrm{v} 7 . \mathrm{i} 5.2019 . P 0519648$

http://dx.doi.org/10.31364/SCIRJ/v7.i5.2019.P0519648

\begin{abstract}
This study examined the influence of Role Conflict, Emotional Fatigue, Job Satisfaction and Organizational Commitment on Teachers of Madrasah Aliyah Negeri in Mataram. Specifically the purpose of this study was to determine the significance of the influence of Role Conflict and Emotional Fatigue on Job Satisfaction and Organizational Commitment. The respondents used in this study were all teachers who taught in State Islamic Senior High Schools (MAN 1 and MAN 2) Mataram as many as $\mathbf{1 3 3}$ teachers. This study uses analysis of structural equation models (SEM analysis) with the application of SmartPLS. The results showed that Role Conflict and Emotional Fatigue had a significant effect on Job Satisfaction, Emotional Fatigue had a significant effect on Organizational Commitment, Role Conflict and Job Satisfaction had no significant effect on Organizational Commitment. Indirectly Job Satisfaction serves as an intermediary variable between Role Conflict and Emotional Fatigue to Organizational Commitment to Teachers of Madrasah Aliyah Negeri in Mataram.
\end{abstract}

Index Terms-Role Conflict, Emotional Fatigue, Job Satisfaction, Organizational Commitment.

\section{INTRODUCTION}

Teachers are often given multiple roles in their duties, this often leads to emotional fatigue felt by the teacher, besides being a teacher at school, teachers have roles in their families, in the environment and others. Such roles give rise to conflicts of expectations from the teacher. Pines and Aronson (1989, in Churiyah, 2011) state that a person who experiences emotional fatigue in individuals associated with personal feelings is characterized by feelings of helplessness and depression. A teacher is basically a job that faces various demands and emotional involvement. Daily interactions with students and coworkers often trigger pressures and challenges that cause emotional tension and can cause stress. When stress in work cannot be avoided some physiological, psychological, and behavioral consequences can occur. This consequence of work conditions that demand and cause stress is defined as Burnout. So that emotional exhaustion is at the core of Burnout syndrome as stated by Malach and Caputo (in Sujtipto, 2001).

Role Conflict is a situation where an individual is faced with different role expectations. The role conflict will arise if the individual finds that being obedient to the demands of one role causes him difficulty in complying with the demands of the other roles (Robbin, 2006). In addition, role conflict arises when management provides a task that cannot be resolved properly by employees due to unavailability of sufficient time and resources (Sumrall \& Sebastianelly 1999, in Permatasari, 2012). The higher the role conflict experienced by a person will further disrupt the performance of employees and have an impact on their satisfaction with the work they carry and their commitment to the organization also decreases.

Emotional fatigue is fatigue in individuals associated with personal feelings characterized by feelings of helplessness and depression (Churiyah, 2011). Emotional fatigue is always preceded by a common symptom, which arises anxiety every time you want to start work. This bad habit turns individuals into frustration or anger at themselves. Anxiety every time you want to start work is a process of emotional exhaustion as the central dimension of another process, which explains behavior in responding to a feeling of fatigue in an employee (Babak 1999, in Churiyah, 2011) 
Job satisfaction is very important to consider for employee self-actualization. Employees who do not get job satisfaction will never reach psychological maturity, and in turn will become frustrated (Handoko, 2007). Job satisfaction is a feedback on the achievement of justice towards awards, because it is very important for individuals and organizations to improve employee commitment to the organization. Related to job satisfaction for teachers in this study is one of the teacher's work attitudes that need to be created while working in school, in order to be able to work with high morale, discipline, enthusiasm, dedication to the profession. Teachers who are satisfied with their institutions will have an impact on the smooth activities when teaching and learning in schools and will be able to improve the quality of services to their students.

According to Salancik (1997, in Santika \& Sudibia, 2017) states that organizational commitment is a stage when an individual becomes bound because of his actions and with that action grows confidence to keep his activities and involvement. Sidharta and Margaretha (2011) explain that organizational commitment is a kind of agreement between individuals in it that is binding and leads to the overall goals of the organization. Committed employees tend to be more responsible in providing services (Santika \& Sudibia, 2017). Various research studies show that people who are relatively satisfied with their work will be more committed to the organization (Mathis \& Jakson, 2011).

Furthermore, Mowday et al (1979 in Croswell, 2006) said that organizational commitment as a relative strength of individual involvement and a sense of identification or shared ownership of individuals towards an organization. Commitment is seen as an attitude (attitudinal) and also as behavior (behavioral). Attitudes related to commitment are attitudes that show harmony between the goals and values of the organization, with the goals and values of the individual. While behavior related to commitment is a behavior that shows the willingness of individuals to release other alternative actions in order to concentrate themselves on behaviors that support and strengthen the organization. Organizational commitment in this case is the commitment of teachers faced with complex types of work and has many aspects and is carried out in a context that has high demands and has emotional and intellectual challenges (Day, 2004 in Croswell, 2006). The teacher as a teacher is a profession that requires a commitment to him in order to maintain active enthusiasm in his work.

Several previous studies from Kusriyani, Magdalena and Paramita (2016), Churiyah (2011) Role Conflict and Emotional Fatigue have a significant negative effect on Organizational Commitment, then studies from Yuliastini and Putra (2015), Santika and Sudibia (2017) Emotional Fatigue have a significant negative effect on Job satisfaction.

This research was conducted departing from the phenomenon of Mataram State Madrasahs, which is based on this school implementing a full day learning model (Fullday school). Learning models that require teachers to continue to innovate in learning systems, where teachers and students are required to attend school for a full day, teachers are required to attend early at 6:30 and leave school at 16:20. With the length of time students study, the teacher is required to be able to modify the existing national curriculum. With the addition of more study hours, this can reflect the characteristics of the school in question.

On the other hand also teachers often face conflicting demands between work and family, in this case female teachers experience greater role conflict than male teachers between work and family, because women are essentially housewives who have obligations and responsibilities against husband and child. Unmarried teachers also have their own version of the role conflict between work in school and outside interest. The role of conflict can also be experienced when internalizing values, ethics, or personal standards that are contrary to the expectations of others.

The consequence of this condition is that the burden of teaching teachers in the school is increasing, not to mention other tasks such as pickets, homerooms, extracurricular counselors, administrative work and other activities. Besides that, it can be seen from the condition of the students (students) in the State Madrasah Aliyah (MAN 1 \& MAN 2) Mataram students come from various ethnic groups and regions, as well as different educational input backgrounds. This difference will add a burden to the teacher, especially in terms of equalizing student perceptions, increasing the workload is not necessarily balanced with a balanced award. This can cause the teacher to experience disappointment, feeling bored, depressed, apathetic towards his work and feeling shackled by these routine tasks. In this study, emotional fatigue is a feeling where a person is depressed and exhausted by a job (Maslach \& Jackson, in Churiyah, 2011). Even though someone who experiences emotional fatigue is characterized by the depletion of emotional resources which ultimately they feel unable to provide services psychologically (Sutjipto, 2001).

This research was carried out departing from the phenomenon that occurred in the State Madrasah Aliyah schools that applied the Fullday School System, where teachers were always required to attend early at school and go home late in the afternoon, consequently the teacher spent a lot of time in school. On the other hand the teacher is required to always innovate in the learning system, the existence of such demands makes conflict within the teacher. Teachers who are demanded as instructors and also hold other responsibilities in school, such as serving as homerooms, pickets, extracurricular counselors, administrative work and other activities, by holding such roles teachers are also faced with a condition of emotional exhaustion characterized by the depletion of resources emotional resources that have an impact on job satisfaction and teacher commitment to the organization where he teaches. Specifically the purpose of this study was to determine the significance of the influence of Role Conflict and Emotional Fatigue on Job Satisfaction and Organizational Commitment to Teachers of Madrasah Aliyah Negeri in Mataram.

\section{LITERATURE REVIEW}

\section{A. Effects of Role Conflict on Organizational Commitment}

Role is a position that has expectations that develop from the norms that are built. An individual often has a dual role because the employee also has a role in his family, in his environment and others. This role often results in conflicting demands and conflicts of hope. The existence of a dual role in the profession as an employee certainly raises role conflicts within employees that have an impact on employee commitment to the organization in which they work (El-Salam 
et al, 2013). From the statement, the first hypothesis in this study can be formulated as follows:

H1: Role Conflict has a significant negative effect on Organizational Commitment

\section{B. Effects of Emotional Fatigue on Organizational Commitments}

The consequences of emotional fatigue are psychological contributions to organizational commitment. Emotional fatigue is an individual response to fatigue experienced outside the prevalence of relationships between employees because emotional impulses are the beginning of a setback of personality which encourages the return of feelings of lack of confidence in an employee which impacts on organizational commitment. In theory, emotional fatigue has a negative influence on organizational commitment, meaning that the higher the emotional fatigue faced by employees, the lower the commitment of employees to the organization due to the fatigue they experience. Conversely, the lower emotional fatigue faced by employees, the higher the commitment of employees to the organization due to the low fatigue felt by employees. The results of the research conducted by Churiyah (2011) show that emotional fatigue affects organizational commitment. From the statement, the second hypothesis of the study is:

H2: Emotional Fatigue has a significant negative effect on Organizational Commitment

\section{Effects of Role Conflict on Job Satisfaction}

Emotional exhaustion is the exhaustion of individuals who are already employed. Each employee has a different level of satisfaction according to the values he adheres to (Solikhan, 2013). From the statement, the third hypothesis in this study can be formulated as follows:

H3: Role Conflict has a significant negative effect on Job Satisfaction

\section{Effect of Emotional Fatigue on Job Satisfaction}

Role is a position that has expectations that develop from the norms that are built. An individual often has a dual role because the employee also has a role in his family, in his environment and others. This role often results in conflicting demands and expectations of the conflict. The existence of a dual role in the profession as an employee certainly raises role conflicts within employees that have an impact on employee job satisfaction (Churiyah, 2011). From the statement, the fourth hypothesis in this study can be formulated as follows:

H4: Emotional Fatigue has a significant negative effect on Job Satisfaction

\section{E. Effect of Job Satisfaction on Organizational Commitments}

Job satisfaction is a general attitude that comes from a number of specific attitudes towards work factors, adjustment and social relations between individuals outside work. Therefore, job satisfaction is a positive attitude that involves healthy adjustment of employees to work conditions and situations, including wages, social conditions, physical conditions and psychological conditions. With the higher job satisfaction perceived by employees, the higher the commitment of employees to the organization (Salim, 2013). From the statement, the fifth hypothesis in this study can be formulated as follows:
H5: Job Satisfaction has a significant positive effect on Organizational Commitment

\section{F. Effect of Role Conflict on Organizational Commitment through Job Satisfaction}

Role is a position that has expectations that develop from the norms that are built. An individual often has a dual role because the employee also has a role in his family, in his environment and others. This role often results in conflicting demands and conflicts of hope. The existence of a dual role in the profession as an employee certainly raises role conflicts within employees that have an impact on employee commitment to the organization in which they work (El-Salam et al, 2013).

According to Hanna and Firnanti (2013) role conflict is a form of discrepancy between bureaucratic control mechanisms and norms, rules, ethics, and independence from professionals. Whereas Rebele and Michaeles (1990), role conflict is defined as the level of incompatibility of expectations communicated by the sender of the role for the obligatory role. Rizzo et al (1970) found that role conflict resulted from the inability of individuals to fully understand the complexity of their corporate organization, from difficulties with interpersonal relationships, from the practice of formal and informal organizations, and from the adequacy or inadequacy of the communication process.

H6: Role Conflict influences Organizational Commitment through Job Satisfaction

\section{G. Effect of Emotional Fatigue on Organizational Commitment through Job Satisfaction}

Job satisfaction is a general attitude that comes from a number of specific attitudes towards work factors, adjustment and social relations between individuals outside work. Therefore, job satisfaction is a positive attitude that involves healthy adjustment of employees to work conditions and situations, including wages, social conditions, physical conditions and psychological conditions. With the higher job satisfaction perceived by employees, the higher the commitment of employees to the organization (Salim, 2013).

H7: Emotional Fatigue affects Organizational Commitment through Job Satisfaction

\section{RESEARCH METHOD}

This research is a quantitative research, using an explanatory and causal approach. In this study aims to determine the pattern of causal relationships between independent variables role conflict and emotional fatigue on organizational commitment through intervening variables of job satisfaction on teachers of Mataram State Madrasah Aliyah. The respondents used in this study were all teachers who taught in State Islamic Senior High Schools (MAN 1 and MAN 2) Mataram as many as 133 teachers. The rate of return of questionnaires by respondents in this study was very high $(100 \%)$, this was because researchers every day came to the study site during the questionnaire distribution. Of the total 133 questionnaires received, 125 questionnaires (93\%) were feasible to analyze. This study uses analysis of structural equation models (SEM analysis) with the application of SmartPLS. 


\section{RESULT AND DISCUSSION}

Structural model testing is done to predict the causal relationship between variables or hypothesis testing, see the significance value, and R-Square research model. The structural model testing aims to predictive relevance and also see the magnitude of the structural path coefficients. The structural testing model is carried out in the SmartPLS application through the bootstrapping process.

The R-Square value is used to calculate the Q-Square test with the aim of predictive relevance, which measures how well the observation value produced by the model and also its parameter estimates. Q-Square values greater than 0 indicate that the model has predictive relevance, while the Q-Square value less than 0 indicates a model that has less predictive relevance. The magnitude of the Q-Square value has a value with a range of $0<\mathrm{Q} 2<1$, where the $\mathrm{Q}$-Square number that is getting closer to number 1 means that the model is getting better.

TABLE I. SQUARE DEPENDENT VARIABLE

\begin{tabular}{|c|c|}
\hline Dependent Variable & R Square \\
\hline Job Satisfaction $(\mathrm{Z})$ & 0,127 \\
\hline Organizational Commitment $(\mathrm{Y})$ & 0,104 \\
\hline
\end{tabular}

Based on the table above, the Q-Square value $=0.026$ or $2.6 \%$ is obtained. This Q-Square value is a value for role conflict and emotional fatigue as an independent variable in this study which gives an influence on organizational commitment through job satisfaction as an intervening variable with a value of $2.6 \%$. This means that this research model has predictive relevance because it has a value greater than 0 , so it can be declared feasible to be used in predictions. The results of this calculation also mean that there are still $74 \%$ of other variables that can affect organizational commitment to Mataram State Madrasah Aliyah teachers.

Based on the results of the study show that there are 3 (three) significant variables influences, while 2 (two) other variables influence are not significant. The influence between independent variables on the dependent variable can be described as follows

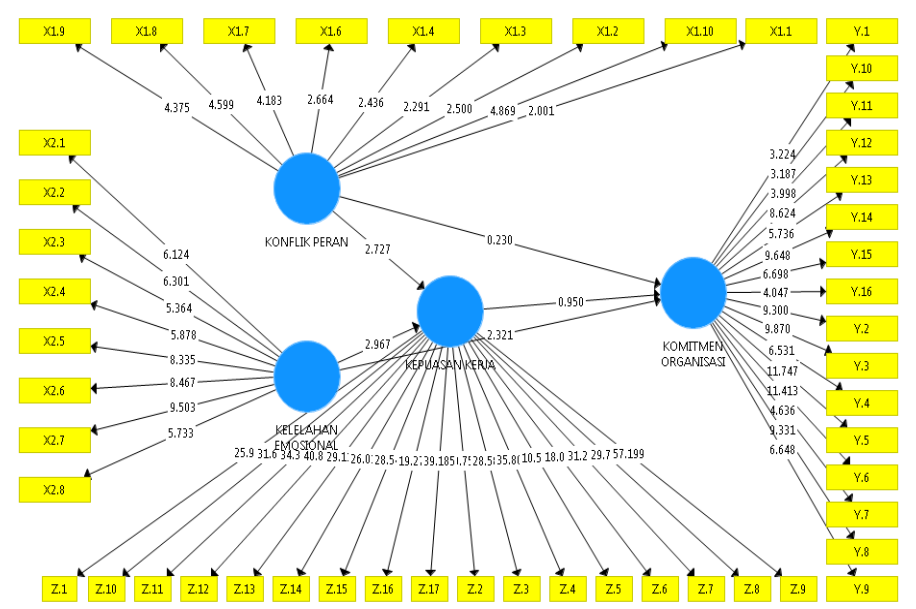

Fig. 1. Effect of Role Conflict and Emotional Fatigue on Job Satisfaction and Organizational Commitment

Testing the research hypothesis by looking at the path coefficient and T-statistic values. Path coefficient testing according to Hartono in Jogiyanto (2011), a measure of the significance of the support of hypotheses can be used to compare the values of $\mathrm{T}$-tables and $\mathrm{T}$-statistics. If the $\mathrm{T}$ statistic value is higher than the T-table value, then the hypothesis is supported. For the 95 percent confidence level (alpha 5\%), the T-table value for the two-tailed hypothesis is $\geqslant 1.64$.

The results of structural model testing can be seen in the table below:

TABLE II. STRUCTURAL MOdEL (INNER MODEL)

\begin{tabular}{|c|c|c|c|c|}
\hline $\begin{array}{c}\text { Inter-Variable } \\
\text { Relationships }\end{array}$ & $\begin{array}{c}\text { Path } \\
\text { Coefficient }\end{array}$ & $\begin{array}{c}\text { T } \\
\text { Statistic }\end{array}$ & $\begin{array}{c}\text { P } \\
\text { Values }\end{array}$ & Description \\
\hline $\mathrm{RC} \rightarrow$ OC & 0,037 & 0,230 & 0,403 & Not Significant \\
\hline EF $\rightarrow$ OC & 0,278 & 2,321 & 0,010 & Significant \\
\hline RC $\rightarrow$ JS & 0,250 & 2,727 & 0,003 & Significant \\
\hline EF $\rightarrow$ JS & $-0,257$ & 2,967 & 0,002 & Significant \\
\hline JS $\rightarrow$ OC & $-0,108$ & 0,950 & 0,171 & Not Significant \\
\hline RC $\rightarrow$ JS $\rightarrow$ OC & $-0,027$ & & & Partial Mediation \\
\hline EF $\rightarrow$ JS $\rightarrow$ OC & 0,016 & & & Partial Mediation \\
\hline
\end{tabular}

Rucker, Preacher, Tomala and Petty (2011) the use of the terms partial mediation and full mediation helps convey the effect size or practical significance of the mediation process. Full mediation demonstration implies that the underlying process can fully relate the independent variable to the dependent variable, while the partial mediation demonstration implies a partial relationship.

1. Hypothesis Testing 1: Effects of Role Conflict on Organizational Commitment

In accordance with the hypothesis that has been built, the first hypothesis states that role conflict for teachers in Mataram State Islamic Senior High Schools has a significant negative effect on organizational commitment. The test results on the parameter coefficient between role conflict to organizational commitment shows a positive influence, where the coefficient value is known as 0.037 and the T-statistic value is 0.230 , meaning that the role conflict in Mataram State Madrasah Aliyah teachers has a not significant positive effect.

2. Testing of Hypothesis 2: Effects of Emotional Fatigue on Organizational Commitment

The second hypothesis states that emotional fatigue has a significant positive effect on organizational commitment. The test results on the parameter coefficient between emotional fatigue to organizational commitment have a positive effect. This is indicated by the coefficient of 0.278 and the T-statistic value of 2.321. So that it can be interpreted that emotional fatigue in Mataram Madrasah Aliyah teachers has a significant positive influence.

3. Testing of Hypothesis 3: Effects of Role Conflict on Job Satisfaction

The third hypothesis in this study states that role conflict in Mataram State Madrasah Aliyah teachers has a significant negative effect on job satisfaction. The test results on the parameter coefficient between the influence of conflict on job satisfaction showed a positive value, with a coefficient value of 0,250 and a T-statistic value of 2,727. The results of this test indicate that role conflict has a significant positive effect on job satisfaction.

4. Testing of Hypothesis 4: Effects of Emotional Fatigue on Job Satisfaction

The fourth hypothesis states that emotional fatigue in Mataram Madrasah Aliyah teachers has a significant negative 
effect on job satisfaction. Based on the test results on the parameter coefficient between emotional fatigue to job satisfaction shows a negative value with a coefficient value of 0.257 and a T-statistic value of 2.967. This test results support the existing hypothesis, because based on the value of $\mathrm{T}$ statistics that are more than 1.64. Thus, it can be concluded that emotional fatigue in Mataram Madrasah Aliyah teachers has a significant negative effect on job satisfaction.

5. Hypothesis Testing 5: Effects of Job Satisfaction on Organizational Commitments

The fifth hypothesis states that job satisfaction for Mataram State Madrasah Aliyah teachers is significantly positive for organizational commitment. The test results on the parameter coefficient between job satisfaction and organizational commitment indicate a negative effect indicated by a coefficient of -0.108 and a statistical T-value of 0.950 . This means that job satisfaction for teachers in Mataram State Madrasah Aliyah has no significant negative effect on organizational commitment.

6. Hypothesis Testing 6: Effects of Role Conflict on Organizational Commitment through Job Satisfaction

The sixth hypothesis states that role conflict in Mataram Madrasah Aliyah teachers has a significant negative effect on organizational commitment through job satisfaction. The results of the test of the magnitude of indirect influence were obtained through the results of the multiplication of path coefficients (beta) between the direct influence of role conflict on job satisfaction and with a direct influence of job satisfaction on organizational commitment to Mataram Madrasah Aliyah teachers. This indirect effect can be seen in the following table:

TABLE III. Perhitungan Pengaruh Tidak Langsung VAriabel KONFLIK PERAN

\begin{tabular}{|c|c|c|}
\hline Pengaruh Variabel & Formula Perhitungan & Hasil \\
\hline Pengaruh Langsung (Direct Effect) & \multicolumn{2}{|c|}{} \\
\hline $\mathrm{KP} \rightarrow \mathrm{KO}$ & - & 0,037 \\
\hline $\mathrm{KP} \rightarrow \mathrm{KK}$ & - & 0,250 \\
\hline $\mathrm{KK} \rightarrow \mathrm{KO}$ & - & $-0,108$ \\
\hline Pengaruh Tidak Langsung & $(0,250 \mathrm{x}-0,108)$ & $-0,027$ \\
\hline $\mathrm{KP} \rightarrow \mathrm{KK} \rightarrow \mathrm{KO}$ &
\end{tabular}

Holmbeck in MacKinnon (2008) states that mediation calculations can be significant even if there is no significant relationship between the independent variable and the dependent variable. Based on Table 3 above, it can provide meaning that there is an indirect influence between role conflict on organizational commitment through job satisfaction with a coefficient of -0.027 . Comparison of the indirect effect of role conflict on organizational commitment through job satisfaction as an intervening variable, with a direct influence between role conflict on organizational commitment with results of $-0.027<0.037$. Thus it can be concluded that job satisfaction serves as an intermediary variable (partial mediation) between role conflict to organizational commitment. This means that role conflict is not able to significantly influence organizational commitment to Mataram State Madrasah Aliyah teachers.

7. Hypothesis Testing 7: Effects of Emotional Fatigue on Organizational Commitment through Job Satisfaction

The final hypothesis in this study states that emotional exhaustion in Mataram Madrasah Aliyah teachers has a significant negative effect on organizational commitment. The results of the test of the magnitude of indirect influence were obtained through the results of multiplying the path coefficient (beta) between the direct effect of job satisfaction on organizational commitment to the teachers of Mataram State Madrasah Aliyah. The value of the calculation of indirect effects can be seen in the following table:

TABLE IV. Perhitungan Pengaruh Tidak Langsung Variabel KONFLIK PERAN

\begin{tabular}{|c|c|c|}
\hline Pengaruh Variabel & Formula Perhitungan & Hasil \\
\hline Pengaruh Langsung (Direct Effect) & \multicolumn{2}{l|}{} \\
\hline $\mathrm{KE} \rightarrow \mathrm{KO}$ & - & 0,278 \\
\hline $\mathrm{KE} \rightarrow \mathrm{KK}$ & - & $-0,257$ \\
\hline $\mathrm{KK} \rightarrow \mathrm{KO}$ & - & $-0,108$ \\
\hline Pengaruh Tidak Langsung & \multicolumn{2}{l}{} \\
\hline $\mathrm{KE} \rightarrow \mathrm{KK} \rightarrow \mathrm{KO}$ & $(-0,257 \mathrm{x}-0,108)$ & $-0,027$ \\
\hline
\end{tabular}

Holmbeck in MacKinnon (2008) states that mediation calculations can be significant even if there is no significant relationship between the independent variable and the dependent variable. The calculation results in Table 4 show that there is an indirect influence between the variables of emotional fatigue on organizational commitment through job satisfaction with the path coefficient value of 0.278 . Comparison of the indirect effect of emotional fatigue on organizational commitment through job satisfaction as an intervening variable, with the direct effect of emotional fatigue on organizational commitment with a result of $0.027<0.278$. Thus, it can be concluded that job satisfaction functions as an intermediary variable between emotional fatigue and organizational commitment. This means that emotional fatigue has a significant effect on organizational commitment even without going through intervening variables of job satisfaction.

Based on the analysis of SmartPLS, the following will explain the discussion of each research hypothesis that has been built. The first hypothesis states that role conflict in Mataram Madrasah Aliyah teachers has a significant positive effect on role conflict. The results of the data analysis show that role conflict in teachers of Mataram State Madrasah Aliyah has no significant positive effect on organizational commitment. This means that the first hypothesis is rejected. This means that if the teacher's role conflict in Mataram State Madrasahs is very high or low, then a teacher will still be committed to the organization in which he works. If seen from the data distribution of respondents, amounting to 133 people. Teacher respondents in Mataram State Islamic Senior High Schools have quite high role conflicts and high levels of organizational commitment. That conformity of instructions and policies received by the teacher as the only aspect of individual conflict with its role has a dominant influence on organizational commitment.

Humans are social beings who have various interests in their lives and every human being is certainly faced with a conflict. According to Winardi (2007) conflict is formulated as a situation where there are goals, cognitions or emotions that are not compatible with each other in individuals or between individuals which then causes antagonistic interactions or interactions. While the role according to Luthans (2005) is defined as a position that has expectations that develop from the norms that are built. Greenhouse and Buutell (2008, in Wirakristama Ginting, 2011) state that role conflict arises due to pressures originating from work. 
Fanani et al (2008, in Rosally \& Jogi, 2015) mention that role conflict can occur when there are two different commands at the same time and between the two commands are the opposite. The role conflict can cause the quality of work to decline because it is not followed by carrying out work. Churiyah (2011) which examines the effect of role conflict on organizational commitment, results that role conflict has a direct and significant effect on organizational commitment, but does not directly influence organizational commitment. This research has theoretical implications that support existing theories and support previous research.

The results of this study found that the role conflict in Mataram State Madrasah Aliyah Teachers had a not significant positive effect on organizational commitment. Thus the high or low role conflict experienced by teachers in the Mataram State Islamic Senior High School, a teacher will remain committed to the organization where he works. This is due to several reasons, among others: 1) the principle that exists in a teacher that working as a teacher is an obligation that must be carried out, with high or low role conflict experienced by the teacher is a task that must be done and will continue to do so, responsible answer and commit to the organization; 2) being a teacher in a State Madrasah Aliyah that applies the Fullday school system is a challenge for teachers who indeed have a full day learning system that is not practiced by other State Schools in Mataram; 3) the understanding of religion possessed by teachers of Mataram State Islamic Madrasah, which is basically always applied in the Madrasa, will encourage teachers to have high organizational commitment to the Mataram Madrasah Aliyah organization. Because by experiencing role conflict in Madrasah the permanent teacher will sincerely carry out the responsibility and continue to teach and practice the knowledge that is owned, it will increase personal knowledge and become useful people. Fourth, each individual has different personal characteristics, has a different mechanism for completing work, and has different tasks, and different responsibilities. So that it will affect self-management and one's commitment to the organization.

The results of data analysis showed that emotional fatigue in Mataram State Madrasah Aliyah Teachers had a significant positive effect on organizational commitment. The second hypothesis states that emotional fatigue in Mataram Madrasah Aliyah teachers has a significant negative effect. This is because a teacher who is exhausted while working still is able to commit to his organization.

Based on respondents' answers to data distribution of 133 people, Mataram State Madrasah Aliyah teacher respondents experienced high emotional fatigue and high levels of organizational commitment. These results do not support the study of Zadlagi (2005) and Churiyah (2011) who say emotional fatigue has a significant effect on organizational commitment. They revealed that employees who experience emotional fatigue will experience low commitment and loyalty.

A person's perception shows that emotional exhaustion experienced by the teacher with the consequences of the Madrasah condition that applies the Fullday School system occurs if the teacher is able to allocate time and energy to work and be responsible for the workload carried out, as well as the time pressure applied to the Madrasah, lack of togetherness with family and feeling that the assignment given by the Principal was excessive. This means that emotional fatigue experienced can make the teacher ignore the duties and responsibilities that have been done.

According to Cherniss (2001, in Santika \& Sudibiya, 2017) emotional fatigue has a negative impact and can affect the work of employees, such as unwillingness to go to work, anger and revenge, feelings of guilt, feelings of failure, discouragement and ignorance, inability to concentrate or listen what the boss said, cynical about coworkers, blaming, and stiff in thinking and surviving unchanging that affect the effectiveness of the organization. When an employee perceives that experiencing emotional fatigue while working due to workload, time pressure, lack of social support and experiencing stress with his role that results in employees spending a lot of time at work, then this will make employees try other alternatives that allow them to keep working.

Furthermore, according to Fredemberger, Caputo, Zadlagi (in Khulub \& Sudibiya, 2012) that fatigue of one's perception that shows emotional exhaustion experienced at work is one of the factors that hold organizational commitment to employees. In this study, Mataram Madrasah Aliyah teachers experienced quite high emotional fatigue, so teachers in Mataram State Madrasah Aliyah felt they could not provide high organizational commitment. Organizational commitment can be interpreted as the psychological state of the teacher which can be seen from loyalty, teacher involvement with the goals, vision and mission set by the Madrasah. So the Mataram State Madrasah Aliyah teachers will still try to carry out their duties and responsibilities well for the work given.

Organizational commitment is also influenced by the length of time someone works for an organization. If seen from teacher respondents from Mataram State Islamic Senior High School, there are teachers who have a tenure of more than 10 (ten) years. That is, the greater the opportunity to get challenging tasks, more challenging autonomy, greater autonomy, freedom of work, only higher extrinsic rewards, and the opportunity to occupy a higher position or position (Risma, 2017). The length of a person working for an organization will increase the strength of one's relationship to the organization he works for.

The results of the data show that the role conflict in Mataram State Madrasah Aliyah teachers has a significant positive effect on job satisfaction, so the third hypothesis which states role conflict in Mataram Mataram Madrasah Aliyah teachers has a significant positive effect on acceptable job satisfaction. This means that if a teacher experiences a low conflict with his work, the higher the satisfaction of his job.

The role conflict experienced by teachers at Mataram State Islamic Senior High Schools is not only at school, at home, as a father or a mother for their children. Almost everyone in their lives is faced with problems in Madrasas. There are problems that can be resolved and some are not able to be resolved. So that teachers who are unable to complete their tasks experience a variety of tension pressures that have an impact on satisfaction with the work they do.

Yousef in Churiyah (2011) that a person who receives a high level of role conflict as a source of stress will be less satisfied with his work. Churiyah (2011) in his study said that emotional fatigue directly and significantly affects job satisfaction. This study provides results that emotional fatigue has a direct and significant effect on teacher job satisfaction, but does not indirectly affect organizational commitment. This 
research has theoretical implications that support existing theories and support previous research.

The results of data analysis showed that there was a significant negative effect of emotional fatigue on teachers of Mataram State Islamic Senior High School towards job satisfaction. The fourth hypothesis in the study said that emotional fatigue in Mataram State Madrasah Aliyah teachers had a significant negative effect on acceptable job satisfaction.

The results of research conducted by Zagladi (2005) examined emotional fatigue on job satisfaction and performance in achieving organizational commitment, revealing that frontline workers who experience emotional fatigue will not feel job satisfaction and cannot show expected performance.

Emotional fatigue is interpreted as the perception of respondents who indicate the condition of emotional fatigue experienced by respondents as a consequence of the conditions at which individuals who are able to do work will be able to minimize the fatigue experienced while working, then they will see themselves as part of the community who are able to do their jobs.

Factors that influence an individual in doing his work are caused by workloads, first is the pressure arising from the work done by someone. As a result the individual feels dissatisfied with the burden given to him. the second time pressure (time pressure) that arises from the tension faced by someone in completing work, where tension can arise from a demand for work completion (deadline), thirdly lack of social support (lack of social support) that is a situation where there is a shortage of support from people around him to do work and the fourth stress because of role (role stress), means that someone experiences an ambiguity towards his work and is facing conflict in his work.

The findings in emotional fatigue research have a significant negative effect on job satisfaction supporting the results of previous studies conducted by Kurnia (2015), Khulub and Hidayati (2012), Sholikhan (2013) and Churiyyah (2011) stating that emotional fatigue felt by employees negatively affects job satisfaction. This opinion is reinforced by Fanani et al (2008, in Rosally \& Jogi, 2015) which states that role conflict can occur when there are two different commands at the same time and between these two commands are the opposite. The role conflict can cause the quality of work to decline because it is not followed by high concentration in carrying out work. Other consequences that can be caused are work being uncomfortable, work tension and various other negative things that have an impact on the results of the work is not optimal. Role conflict occurs when an employee faces expectations that are not as expected, so that what is expected is not created effectively.

The results of data analysis show that there is a significant negative effect of the Mataram Madrasah Aliyah teachers' work on organizational commitment. This means that the hypothesis which states that the work satisfaction of Mataram State Madrasah Aliyah teachers has a significant positive effect on organizational commitment is rejected. This means that if someone feels dissatisfied with the work, the teacher does not commit to the organization. In other words the lower the teacher's job satisfaction, the lower the commitment to the organization.

Based on the results of the analysis show that organizational commitment is not influenced by role conflict and job satisfaction functions as an intermediary variable (partial mediation) between role conflict to organizational commitment. This means that role conflict is not able to significantly influence organizational commitment to teachers of Mataram State Madrasah Aliyah without going through intervening variables of job satisfaction. The results of this study illustrate that a teacher who experiences high or low conflict with his role at work, will still feel satisfaction with the work he does, so it remains for high organizational commitment.

Role conflict as a form of confusion of the role that must be performed by the teacher that occurs because of carrying out more than one conflicting role, because there are multiple instructions that are different from each other and must be done at the same time, and there is a mismatch between the roles to be performed and the demands should be based on certain professional standards that are believed and adhered to. According to Luthans (2005, in Rizki, 2012), a person who has a role conflict if he has two or more roles that must be run at the same time, so that it becomes one of the factors that influence organizational commitment to employees. In this study, although Mataram State Madrasah Aliyah teachers have high role conflicts, but teachers still have high organizational commitment.

Based on the results of the analysis show that organizational commitment is not influenced by emotional fatigue and job satisfaction functions as an intermediary variable (partial mediation) between role conflict to organizational commitment. This means that emotional fatigue is not able to significantly influence organizational commitment to teachers of Mataram State Madrasah Aliyah without going through intervening variables of job satisfaction. The results of this study illustrate that a teacher who experiences high or low emotional fatigue with assignments at work, will still feel satisfaction with the work done, so it remains for high organizational commitment.

Emotional fatigue experienced by the teacher is self-fatigue associated with personal feelings about the workload given by the organization, where the teacher experiences high emotional fatigue which results in not being able to complete some of the tasks he is carrying, with workloads that make the teacher not impact teacher loyalty to the organization, the teacher remains committed to the organization even though the teacher experiences high fatigue.

The organizational commitment shown by the teacher to what extent the teacher can contribute and loyalty to the organization. In line with fulfilling their daily needs. The existence of attitudes and loyal attitudes towards the organization reflects the attitude of the life experience of a teacher, which is based on the awareness of the responsibility of his work.

The results of this study support the research conducted by Churiyyah (2011) who found that emotional fatigue had a nonsignificant positive influence on the organizational commitment of Madrasah Tsanawiyah teachers. These results indicate that teachers who experience fatigue while teaching still give their loyalty to the organization. Thus it can be concluded that emotional fatigue has an influence on organizational commitment both directly and through the intervening of job satisfaction so that it can be concluded that teachers from Mataram State Islamic Schools who feel 
emotional fatigue while working will remain committed to their organization.

\section{CONCLUSION}

The results of data analysis show that role conflict in Mataram State Madrasah Aliyah teachers has a not significant positive influence on organizational commitment, this means that if the teacher's role conflict in Mataram State Madrasah Aliyah is very high or low, then a teacher will remain committed to the organization in which he works . Emotional fatigue for Mataram State Madrasah Aliyah teachers has a significant positive effect on organizational commitment, this is because a teacher who is exhausted while working still is able to commit to his organization. Role conflict in Mataram Mataram Madrasah Aliyah teachers has a significant positive effect on job satisfaction, meaning that if a teacher experiences a low conflict with his job, the higher the satisfaction of his job. Emotional fatigue in Mataram Madrasah Aliyah teachers has a significant negative effect on job satisfaction. The teacher work authority of the Mataram State Madrasah Aliyah has no significant negative effect on organizational commitment, meaning that if a person feels dissatisfaction with his work makes the teacher not committed to his organization. Organizational commitment is not affected by role conflict and job satisfaction functions as an intermediary variable between role conflict and organizational commitment. This means that role role conflict can significantly influence organizational commitment to teachers of Mataram State Madrasah Aliyah without going through the variable job satisfaction. Organizational commitment is influenced by emotional fatigue through job satisfaction as an intervening variable for Mataram Madrasah Aliyah teachers, meaning emotional fatigue can significantly influence organizational commitment to Mataram Madrasah Aliyah teachers directly or indirectly through job satisfaction.

The practical implications of the results of this study were pointed out to the Principals of Mataram State Madrasah Aliyah (MAN 1 \& MAN 2), and especially to teachers who taught in both Madrasas by efforts to increase teacher resources programmed through clear division of work tasks, workloads that according to ability and motivation. For Mataram State Islamic Madrasahs that apply the Fullday school system, it is expected that teachers who experience role conflict and high emotional fatigue are minimized, even though these teachers remain satisfied and committed to the organization and should be maintained, while maintaining a balance between tasks, workloads that not excessive. The existence of this research can be used for consideration for Mataram State Islamic Senior High Schools so that they can pay attention to teachers who experience role conflict and emotional fatigue at work.

\section{REFERENCES}

[1] Croswell, Leanne, Elliott, Bob. (2006), Committed Teachers, Passionate Teachers: the dimension of passion associated with teacher commitment and engagement, http://www.aare.edu.au/04pap/cro04237.pdf, Juni 2018

[2] Churiyah, Madziatul. (2011), "Pengaruh Konflik Peran, Kelelahan Emosional terhadap Kepuasan Kerja dan Komitmen Organisasi”, Jurnal Ekonomi Bisnis. XVI (2), 145-165.
[3] Hanna, E., \& Firnanti, F. (2013), "Faktor-faktor yang mempengaruhi Kinerja Auditor", Jurnal Bisnis dan Akuntansi, XV (1), 13-28

[4] Handoko, Hani, (2007). Manajemen Sumber Personalia dan Sumber Daya, Yogyakarta: Liberty

[5] Khulub, Tanwirul, \& Hidayati A., Lukluk. (2012), "Peran ganda dan kelelahan emosional terhadap komitmen organisasi dengan kepuasan kerja sebagai variabel Mediasi pada karyawati CV. Nika Indonesia”, Jurnal Maksipreneur, II (1), 1-19

[6] Kusriyani, Theresia., Magdalena, M., \& Paramita, D., P. (2016) "Pengaruh konflik peran, kelelahan emosioanl dan kepuasan kerja terhadap intensitas turnover yang dimediasi komitmen organisasi pada Dinas Pasar Kota Semarang”, Journal of Management, II (2).

[7] Luthans, Freed. (2005), Organizational Behavior, (ninth edition). New York: Mc Graw Hill

[8] Mathis, R.L \& Jackson. (2011), Human Resource Management. Jakarta: Salemba Empat.

[9] Mohamed A. Rageb, Eman Mohamed Abd El-Salam, Ahmed El-Samadicy dan Shaimaa farid. (2013), Organizational Commitment, Job Satisfaction and Job Performance as a mediator between Role Stressors and Turnover Intentions A Study from an Egyptian cultural perspective. The Business and Management Review Vol. 3 No. 2 Januari 2013 p.51-73

[10] Permatasari, Devi. (2012), Analisis factor-faktor yang mempengaruhi keinginan Berpindah Auditor pada Kantor Akuntan Publik di Jawa Tengah dan DIY. Jurnal Aset, XIV (1), $1-3$.

[11] Rizzo, J. R., Lirtzman. (1970), Role Conflict and Ambiguity in Cmplex Organizations. Jurnal of Administrative. 150-161

[12] Rebele, J. E., \& Michaels, R.E (1990), Independent Auditors Role Stress: Antecedent Auditor, Outcomes, an Moderating Variables. Bevhavior Research ini Accounting. Vol 2.

[13] Robbins, S. (2006). Organizational Behavior, New Jersey. USA. Prentice- Hall International, Inc

[14] Rosally, Catherina., \& Jogi, Yulius. (2015), "Pengaruh konflik peran, ketidak jelasan peran, dan komitmen organisasi terhadap kinerja Auditor", Jurnal Akuntansi Bisnis, III (2).

[15] Salim, Agus. (2013), "Pengaruh Kepuasan Kerja terhadap Komitmen Organisasional, Kinerja dan Turnover Itention pada Karyawan PT. Indospring di Kota Gresik", Jurnal Penelitian

[16] Santika, B., Putu., \& Sudibia, A., Gede. (2017), "Pengaruh kelelahan emosional terhadap kepuasan kerja dan komitmen organisasional", Jurnal Manajemen Unud, VI (2), 634-662

[17] Sholikhan, (2013), "Pengaruh Kelelahan Emosional terhadap Kepuasan Kerja dan Dampaknya terhadap Kinerja Guru”, Jurnal Ekonomi Modernisasi Fakultas Ekonomi, Malang: Universitas Kanjuruhan Malang

[18] Sidharta., \& Margaretha. (2011), "Dampak komitmen organisasi dan kepuasan kerja terhadap Turnover Intention: Studi Empiris pada karyawan Bagian Operator di salah satu Perusahaan Garment di Cimahi”, Jurnal Manajemen, X (2), 129-142

[19] Winardi, J. (2007). Teori Organisasi \& Pengorganisasian. Rajawali Pers: Jakarta

[20] Yuliastini, Dyna. Wayan. Ni. \& Putra.Surya. Made. (2015), "Pengaruh Kelelahan Emosional terhadap Kepuasan Kerja Guru SMK di Denpasar", E-Jurnal Mnajemen Unud, IV (4). 